\title{
Russian Open Education Centre "Siberia.ru": the Conceptual Bases and Prospects for Development
}

\author{
Galina A. Kopnina, Irina V. Evseeva, \\ Ekaterina V. Eremina, Tatiana K. Verenich \\ and Irina V. Bashkova \\ Siberian Federal University \\ Krasnoyarsk, Russian Federation
}

Received 26.10.2020, received in revised form 30.11.2020, accepted 15.12.2020

\begin{abstract}
The article describes the experience of organising the Russian Open Education Centre at Siberian Federal University with the support of the Ministry of Education of the Russian Federation by giving the brief overview of the most common approaches to defining the term "open education", pointing out the structural and target differences of the centres for open education and distant learning found in some Russian universities, presenting a detailed description of the conceptual grounds and the prospects for the development of the Russian Open Education Centre at Siberian Federal University as well as the courses, workshops and cultural events held in October and November 2020 for the participants learning Russian as a foreign language from more than 70 countries.
\end{abstract}

Keywords: open education, open education centre, Russian as a foreign language, Russian as the second language, Russian culture.

The study was carried out with the support of the Ministry of Education of the Russian Federation (subsidies for the implementation of measures aimed at the full functioning and development of the Russian language, the departmental target programme "Scientific, methodological and staffing support for teaching the Russian language and the languages of the peoples of the Russian Federation", subprogramme "Improving the management of the education system" of the state programme of the Russian Federation "Education development").

Research area: philology.

Citation: Kopnina, G.A., Evseeva, I.V., Eremina, E.V., Verenich, T.K., Bashkova, I.V. (2020). Russian open education centre "Siberia.ru": the conceptual bases and prospects for development. J. Sib. Fed. Univ. Humanit. Soc. Sci., 13(12), 1952-1961. DOI: 10.17516/1997-1370-0683.

(C) Siberian Federal University. All rights reserved

* Corresponding author E-mail address: okopnin@mail.ru, ivevseeva@yandex.ru, katyaeremina@mail.ru, tverenich@mail.ru ORCID: 0000-0001-9883-3892 (Kopnina); 0000-0003-0495-033X (Evseeva); 0000-0002-3924-178X (Eremina); 0000-00022033-5647 (Verenich); 0000-0003-0318-1436 (Bashkova) 


\section{Introduction}

In the last decade, the concept of open education has been actively implemented in Russia: hundreds of online platforms have been created, which, according to experts, allow "more than 900 universities around the world to implement a total of 11.4 thousand MOOCs, and about 2,000 of them were created in 2018". However, the vast majority of online courses (about $80 \%$ ) are in English, while only $2.5 \%$ of the total number of online courses is in Russian (Yaskevich, 2019: 80). It is courses in Russian in various fields of knowledge that are gaining more and more popularity. For example, "one of the most popular courses ever launched on the Coursera platform is the course on robotics in Russian developed by the professors of Moscow Institute of Physics and Technology" (Yaskevich, 2019: 81). The development of open education in Russian, as it is an urgent need of society, is becoming an important element of the education system in Russia, including higher education.

It is not only teaching in Russian as the state language of Russia that is of particular importance, but also teaching Russian as a non-native and foreign language. The latter is strategically important for Russia right now, when from time to time the Russian language acts as a target of informational and psychological aggression. As evidence, a number of defamatory reports can be cited that the Russian language will be deprived of the status of the official language of the UN and other international organisation. "As explained by Jim Noland, an employee of the Harvard Linguistic Research Group, which consulted the UN on this issue, Russian became a working language of the UN only under pressure from the Stalinist USSR during the creation of the organisation. In fact, it never deserved that status. $<\ldots>$... the area of the Russian Surzhyk distribution in five years will be only the former RF project, which will soon disintegrate, Belarus and partly Kazakhstan. This does not give reason to leave Russian as the working language of the UN, says Jim Noland". "The Institute of Linguistics in Tartu (former Academy of Linguistics of the USSR) announced that monitoring carried out annually by the
Institute's staff showed that the artificial Russian Surzhyk ceased to meet the minimum requirements for self-identity, richness of vocabulary and application", ReporterUA writes"; "... the Russian language will soon be declared a dead language" (OON lishit ..., 2015). Such information attacks are not a coincidence. The Russian language is one of six working languages aimed to provide international communication and relations for peace purposes (it is included into the club of socalled "world languages"), therefore preserving and supporting the status of the Russian language as the world language is admitting the right of Russia as a state to present and defend its interests abroad in Russian in the $21^{\text {st }}$ century as well, which is clearly the century of global communication, the century of the Internet. Moreover, the Russian language is interesting and consistent in the world not only as an academic subject, but also as a carrier of non-military Russian culture, its highly moral national values and interests. Improving the quality of its teaching and "the attractiveness of education in Russian on the world market of educational services" is part of the "National Security Strategy of the Russian Federation" (Strategiia ..., 2015).

In 2014, the Council for the Russian Language was created under the auspices of the President of the Russian Federation, which included leading Russian philologists and linguists, as well as teachers, historians of Russian literature, directors of literary museums, writers and publishers. The President considers the work of this Council to be a serious instrument with a large-scale task to form "an active and holistic language policy that will ensure the preservation and development of the Russian language and literature both in Russia and in the world" (Stenogramma Zasedaniia Soveta ..., 2019). At the last meeting of the Council, which took place on November 5, 2019, Vladimir Putin once again emphasised the importance of ensuring the development, protection and support of the Russian language in the modern geopolitical situation: "We, our country have a huge responsibility for the preservation, development and dissemination of the Russian language and literature, especially to- 
day, when we face the attempts to artificially reduce - I want to emphasise this - precisely artificially, roughly, sometimes absolutely blatantly, the space of the Russian language in the world, to push it to the periphery. It is not only cave Russophobes who declare war to the Russian language - this is something we also observe and I think it is not a secret - all sorts of marginalised people are actively working here, as well as aggressive nationalists. Unfortunately, in some countries this is becoming quite an official government policy, behind which - and this should be also clear and understandable there is the same pressure, direct violation of human rights, including the right to a native language, culture and historical memory. In these conditions, we are facing two equally important tasks. The first one is to ensure a decent level of knowledge, general literacy of Russian citizens and thereby global competitiveness, the attractiveness of the Russian language as a modern, lively, dynamically developing means of communication. The second one is to implement an effective system of support for the Russian language environment abroad in the informational, educational and humanitarian fields" (Stenogramma Zasedaniia Soveta ..., 2019).

In modern geopolitical conditions, the promotion and popularisation of the Russian language is a priority in the state policy in the field of language education, which is repeatedly emphasised by Vladimir Putin. "The Russian language unites all the peoples of Russia. It is the basis of our national identity, our great heritage, unique in its imagery, clarity, accuracy, expressiveness and beauty. Probably, these qualities of the language, are the secret of the greatness and attractiveness of Russian literature, Russian culture, which the whole world admires, serves as a standard for many genres of world art" (Stenogramma vstrechi ..., 2020).

Everything mentioned above determines the relevance of the creation of the Russian Open Education Centre "Sibir.ru" at the Institute of Philology and Language Communication of Siberian Federal University to popularise the Russian language, literature and culture in full-time and distance learning format among foreign citizens.

\section{Brief analytical overview \\ of open education centres}

The principles of variability (creating conditions for choosing a form of study, an online programme (Bakieva, 2019: 83)), accessibility (providing everyone, regardless of their age, place of residence, social status, the opportunity to access high-quality educational resources (Yaskevich, 2019: 79)), continuity of education (learning at any age and without interrupting study/work), individualisation (individualisation of goals, content, schedule and rhythm of learning, forms of control; the latter is characteristic of continuing education and professional development), fundamental nature of educational programmes and some others made open education "a powerful tool in the struggle of many universities and national education systems for students and listeners" (Yaskevich, 2019: 79).

Foreign experience of open education is primarily associated with the establishment and functioning of open universities. The most striking example of such an organisation of educational process is the Open University of Great Britain founded in 1969. The main goal of this university is to provide an opportunity to get education to those people who want to study in a convenient place and at a convenient time by means of "delivering teachers to adult students' homes" and training in accordance with an accelerated flexible system of autonomous courses for a relatively low fee (Alan Tait, 2008). However, in our opinion, metaphors such as "delivering teachers to their homes" form an incorrect idea of education as a service sector.

The experience of creating centres for teaching the Russian language abroad is represented mainly by the Russian centres of science and culture (RCSC) operating in 58 countries of the world under the auspices and with the support of Rossotrudnichestvo (Federal Agency for the Commonwealth of Independent States Affairs, Compatriots Living Abroad, and International Humanitarian Cooperation). A distinctive feature of the work of these centres is the social and professional orientation of the courses, orientation of teaching various target audiences, and the main goal of the RCSC 
is to attract students for studying and subsequent employment in Russia.

The development of open education in Russia was facilitated by the creation in 2015 of the "National Platform for Open Education" Association, which included Lomonosov Moscow State University, SPbU, SPbPU, NUST MISIS, NRU HSE, MIPT, UrFU and ITMO University. In 2020, 664 online courses were presented on the Open Education platform for the implementation of basic educational programmes, in the development of which 16 universities took part (https://openedu.ru/partners/apply).

Currently, open education centres operate in various universities in Russia. Without pretending to be a complete analytical review, let us note some fundamental differences between the centres, which are structural divisions of universities, and not private organisations.

Many open education centres existing at Russian universities are characterised, as we understand it, by a complex structure and multifunctionality. For example, N.A. Ivanova in her 2009 publication writes that the Open Education Centre of Saratov State University established in 2006, solved the problems of coordinating the activities of the university "regarding the issues of pre-university education, organisational and methodological support of part-time and distance education, as well as the development of open education." The centre supervised the work of " 13 faculties, 4 institutes and 2 colleges, providing training in more than 40 specialties and areas of higher and vocational education" (Ivanova, 2009: 71). The structure of the centre included a distance education department, a knowledge quality department, an editorial and publishing department, a preparatory department and preparatory courses. Within its framework, competitions were held for school students in various areas, international contests, school scientific and practical conferences (Ivanova, 2009: 74). As you can see, this centre performed organisational, methodological, publishing, educational and supervising functions. The organisation of distance learning was only one of the directions of its work. Probably, later this unit was restructured, since in September 2009 at Saratov National Research State University named after I.N.G. Chernyshevsky, the Centre for Open Education (the one there is information about on the university website) aimed at the development of distance education in various directions, took place again. At the moment, the structure of this university includes the Institute of Electronic and Distance Learning [https://www.sgu.ru/structure/openedu].

Not all university open education centres develop online education for a broad audience as a line of activities. It is not indicated, for example, in the list of activities of the Interdisciplinary Open Education Centre as a structural unit of the Institute of Continuing Pedagogical Education of Novgorod State University named after Yaroslav the Wise. This centre has existed since 1999 and deals with issues of cooperation with scientific and educational associations of the Institute, planning and supporting publishing activities at the Institute, providing scientific and methodological support for the modernisation of general and pedagogical education and some others (https://www.novsu.ru/ dept/ 20876/).

The functionality of other open education centres is limited, for example, by solving the issues of distance education (such is the Institute of Open (Distance) Education of the State University of Management (http://ioo.guu.ru/)) or additional education of schoolchildren in some subjects (see Centre for System Technologies of Open Education of the Department of Pre-university Training and Additional Educational Services of Nizhny Novgorod State Technical University named after R.E. Alekseev (https://www.nntu.ru/phonebook/view/ spravochnik/csto)).

There is also a tendency to set open education equal to distance education. For example, the Centre for Open Education of the Department of Information Systems and Technology of Ulyanovsk State Technical University implements distance education on a paid basis in a number of specialties (http://coe.ulstu.ru/index. php?action=show_page\&id=108); the Centre for Open Education of Volgograd State Technical University was named a Distance Learning 
System (http://vstu.ru/university/press-center/ news/obrazovanie/tsentr_otkrytogo_obrazovaniya_volggtu/).

Therefore, even at a glimpse one can state that the phrase "open education" is fashionable in the modern educational environment, though it has a lot of meanings. Not all open education centres have their own online platforms and not all of them are purposefully targeted at foreigners.

We believe that the Internet portal "Education in Russian", which mission is "teaching Russian as a foreign language, popularising and promoting the Russian language and education in Russian in the world" created at the State Institute of the Russian Language named after V.I. A.S. Pushkin fully complies with the idea of open education (https://pushkininstitute.ru/about). It contains various educational resources and online services aimed at teaching the Russian language at all levels, improving the qualifications and professional retraining of Russian language teachers, teaching Russian to bilingual children; offers author's online courses and online lessons, videos about the Russian language, literature, culture and education in Russian for a wide range of users, competitions, contests in the Russian language and literature for students; provides news and announcements of events in the world of the Russian language, etc. With its broad capabilities, the Internet portal is accessible to everyone and is a platform for interaction between partner organisations that share the principles of its work. Siberian Federal University adheres to the same ideology of educational openness and the importance of popularising and promoting the Russian language and education in Russian.

Initiated by the Ministry of Education of the Russian Federation, the target programme "Scientific, methodological and staffing support for teaching the Russian language and the languages of the peoples of the Russian Federation" is a platform for consolidating the accumulated methodological and didactic experience in the field of teaching Russian as a foreign language and its implementation by initiative groups in specific educational proposals and projects.
Centres for open education in Russian for foreigners with the support of the Ministry of Education of the Russian Federation are opening this year at several universities in the country:

- Siberian Centre for Open Education in Russian for Foreign Citizens at Altai State Pedagogical University; its functions include "implementation of education, information and consulting activities, development and implementation of educational courses and educational activities in the Russian language for foreign citizens" (https://politsib.ru/ news/40094-sibirskij-centr-otkrytogo-obrazovania-na-russkom-azyke-dla-inostrancev-otkroetsa-v-altgpu);

- Centre for Open Education for Foreigners "Pushkin Centre" at Perm State Humanitarian Pedagogical University; it is planned to organise distance Russian Language educational courses in Russian for foreign citizens, educational events on the history of the Urals, the literary heritage of Perm and the culture of Russia (https://pspu.ru/press-centr/ news?id=19888);

- Centre for Open Education in Russian for Foreigners at Novosibirsk State Pedagogical University; under the auspices of the centre "students will get engaged in research work in the field of philology, communication theory and applied linguistics, studying the culture of Russian speech and Russian speech circulation" (https://futurerussia.gov.ru/nacionalnye-proekty/russkoazycnyj-centr-obrazovania-dla-inostrancev-sozdadut-v-novosibirskom-vuze-ngpu].

With the support of the Ministry of Education of the Russian Federation (subsidies for the implementation of measures aimed at the full functioning and development of the Russian language, the departmental target programme "Scientific, methodological and staffing support for teaching the Russian language and the languages of the peoples of the Russian Federation", subprogramme "Improving the management of the education system" of the state programme of the Russian Federation "Development of Education"), the Russian Open Education Centre has also started its work at Siberian Federal University. 


\section{Conceptual bases for opening the Russian Open Education Centre "Siberia.ru"}

Establishment of "Siberia.ru" Centre on the basis of Siberian Federal University is determined by the following initial provisions.

1. We regard open education "not as an established social institution and not even as a project or concept, but as an inspiring metaphor that collects our ideas about new, effective, time-appropriate education that sets the prospects for cultural and socio-economic development of Russia and the Krasnoyarsk Krai" (Efimov, 2015: 20), and as a prerequisite for the development of a modern education system in the Russian Federation.

A prerequisite for successful work with foreigners is the implementation of new approaches to the formation of educational content in the conditions of the education process going beyond a certain age, place and traditional attitudes (people start to study earlier, finish later, study at home, at school, and on the way, etc.), on the one hand, and the latest information technologies improving the productivity of educational work, contributing to the individualisation of educational trajectories, on the other hand.

SibFU signed agreements on international cooperation with 48 countries of the world. The future of the university is unthinkable without interaction between countries in the educational and scientific fields.

2. The language policy of the university is associated with the positioning of the Russian language as a marker of civic self-identification, a tool for consolidating Russian society and an effective means of strengthening the status of the Russian Federation in the world arena.

It is expected that "Sibir.ru" Centre will become one of the key elements of the system of language propaedeutic training of foreign citizens for further obtaining of higher education in Russia; will contribute to the successful cultural integration of foreign citizens and their entry into the Russian community through getting to know its social, cultural and social norms. Thus, opening of this Centre fully cor- responds to one of the goals of the national project "The Future of Russia" in the field of education, i.e. "to make higher education in Russia attractive to foreigners" (Natsional'nyi proekt ... 2020).

3 . The open education system is based on distance learning technology; therefore, it is important to have an information and educational platform that ensures the availability of high-quality educational resources, freedom of choice, etc.

The website of the Open Education Centre "Sibir.ru" is under development, currently its employees are creating and launching e-courses on the "e-Siberia" platform, which is an online learning platform of the Siberian Regional Centre of Competence in the field of online learning in Krasnoyarsk (https://online. sfu-kras.ru/?lang=es), in fact expanding the list of the main areas of its work. At the same time, the use of digital distance educational technologies does not negate the possibilities of organising classes in full-time mode.

4. One of the indicators of the openness of the educational space is a wide range of educational proposals (Eremin, Orlova, 2020: 47), which makes it possible to interest and attract people from different countries as learners. The work of the Russian Open Education Centre for foreigners contributes to the solution of this problem.

In 2020, as part of the opening of the Centre, foreign citizens were offered a number of various educational courses. As a result, people from countries such as Australia, Austria, Azerbaijan, Algeria, England, Argentina, Belgium, Bolivia, Bulgaria, Brazil, Hungary, Venezuela, Vietnam, Honduras, Haiti, Germany, Guatemala, Greece, Egypt, Israel, India, Indonesia, Iraq, Ireland, Spain, Italy, Cameroon, Cyprus, China, Colombia, Cuba, Lithuania, South Korea, Kyrgyzstan, Mexico, Moldova, Mongolia, Morocco, Myanmar (Burma), Nigeria, Nicaragua, Pakistan, Peru, Poland, Romania, El Salvador, Serbia, Slovakia, USA, Thailand, Tajikistan, Tanzania, Turkey, Tunisia, Uganda, Uzbekistan, Ukraine, France, Croatia, Czech Republic, Sweden, Ecuador, Estonia and Japan have registered for distance courses and online outreach events. 
5. The priority task of open education is to form educational content in accordance with the new cognitive needs of society, the connection between education and culture as the basis for the development of society.

The integration of cultural and educational components in the content contributes to a more successful positioning and promotion of the region abroad, helps to form the image of the region and significantly affects the perception of the country in the world space. This approach gives particular relevance to the project, since it is based on the position of the modern urbanistic theory, which states that in the modern world, when choosing a place to live, work or study, a person is guided not by a country, but by a specific region or city taking into account the possibilities of its comfortable and cultural environment.

The focus on creating universal courses (aimed at students of different ages, with different levels of academic education, different social and national identities), unique in content and methodology, ensures the saturation of the educational process, its flexibility and variability, which, given the fundamental availability of information and the complexity of differentiating essential knowledge from information noise, is of particular relevance.

6 . When organising the work of the Centre, special attention is paid to the target audience, namely, taking into account modern features and characteristics of the new generation of students. The availability of almost any information, gamification in education and work, availability of various gadgets with Internet access - all these features determine the development of the modern education system.

Modern students are characterised by multitasking, fast learning, active and high-quality information processing, the ability to instantly switch from one type of activity to another. They are able to perceive the world through short videos (as in social networks like Instagram and TikTok), through small articles (typical for such platforms as Facebook, Instagram, VKontakte) and through pictures, images and messages. Such messages can be video clips, pictures or graphic images, which can be pre- sented in a variety of formats - posts, stories, reposts, etc. Methods of working with a new type of students are based on the principles of providing information "briefly, simply and explicitly” (Poláková, 2019).

The developers of educational courses face the tasks related not only to deepening the knowledge about the characteristics of the modern target audience, but also to finding forms, methods and means of modernising the education process itself.

7. Teaching the Russian language is not only an educational, but also awareness-raising task, which is solved through an appeal to Russian culture and literature.

The Corresponding Member of the Russian Academy of Sciences N.N. Skatov says, "Our culture is peculiar in many ways, it is verbal. Our people are one of the few in whose history the word plays such an important role" (On the Russian Word, 2007). Therefore, the Centre offers educational courses in Russian literature, which has a powerful educational potential, master classes in song culture, etc.

\section{Areas of work \\ of the Russian Open Education Centre "Siberia.ru"}

At the initial stage of the Centre's work, the developers of the project considered four priority areas.

1. The main activity of the Centre is the development, organisation and implementation of general educational distance courses for the audience speaking other languages.

In October - November 2020, international students were able to complete free courses (the scope of one course varies from one to two credits):

- "Your Siberian holidays" (for students who start learning Russian), which provides the knowledge of basic grammar and vocabulary of the Russian language in an interactive video form with tasks for each lesson;

- Russian country studies ("Rossievedenie") (required Russian language level B1 and higher) devoted to geography and climate of Russia, cultural traditions and customs, Krasnoyarsk city and its landmarks; 
- Pro-reading course (for international students with Russian language level $\mathrm{B} 2+$ and higher) devoted to the major Russian classical writers and Russian literature processes of the modern time;

- "About Russian in Russian" course, which allowed international students with the Russian language level of B2+ to learn about the expressive means of the Russian phonetics, vocabulary and phraseology of the Russian language, key word building methods, peculiarities of Russian speaking etiquette.

Contact work with teachers involves work in an interactive format through video conferencing systems (Zoom, Google Meet) and assignments for independent work, training and test materials are posted on e-Siberia. Courses on the e-Siberia platform allow to learn the content of the courses in a deferred time format (there is no public access to lectures and presentation materials, but students have an opportunity to view and return to them throughout the course). Final tests are also provided.

2. Development and implementation in a distance format of informational and outreach events devoted to Russian culture.

In October and November, the Centre held several events of different kinds:

- Music lesson "S pesnei po zhizni" (Singing for a lifetime) (required Russian language level $\mathrm{A} 2+$ and higher) devoted to the singing culture of Russia;

- Master class "Siberian pelmeni" (required Russian language level A2+ and higher), which was aimed at presenting Siberian cuisine, recipes and food traditions and teaching to cook pelmeni guided by a chef;

- Series of classes on Russian decorative art (required Russian language level $\mathrm{A} 2+$ and higher), which allowed students to get to know Russian crafts, their history and Russian traditions; make a Russian doll and try one's hand in traditional Russian painting;

- Floor game "Walking around Russia" (required Russian language level B1 and higher), which is a team game aimed at consolidating knowledge of Russian studies;

- Game "Philological football" (required Russian language level B1 and higher), which is a team game aimed at consolidated the knowledge of the Russian language".

3. Organisation and conduct of methodological online seminars on the results of the Centre's work and exchange of experience.

Researchers note a significant number of positive aspects of electronic and distance education, but at the same time they write that "the use of new electronic technologies does not automatically lead to an improvement in the quality of the educational process" and that "unfortunately, today we can increasingly observe how active learning is replaced by the search for information, and its accumulation is not accompanied by comprehension. Such mental passivity turns into a situation of "knowledge without consciousness"' (Parygina, Terov, 2016: 115). In this situation, the exchange of experience aimed at improving the open education system becomes extremely important. Moreover, the staff of the "Sibir. ru" Open Education Centre consists mainly of young teachers, who are ready not only to teach Russian to foreigners, but also to study themselves.

4. Informational support of the work of the Centre in social networks.

At the moment, information about the activities of the Centre is covered in several languages (Russian, English, Chinese, Spanish) on the page of the Department of Socio-Cultural Adaptation of Foreign Citizens of Siberian Federal University in VKontakte network, on the page of SibFU in Twitter, on Instagram, Telegram, Weisbo and Facebook.

\section{Conclusion}

The establishment of the Russian Open Education Centre "Sibir.ru" at Siberian Federal University is an important and, hopefully, a significant link in the overall system of centres, which activities are aimed at promoting the Russian language, literature and culture in the world. Our university is a university open to the world.

It is very important for the national security of the state that our young generation and middle-aged people know Russia, its traditions, history and culture well. Therefore, the Centre should develop in two directions: 
Russian studies for foreigners and Russian studies for our compatriots living abroad, as well as Russians representing small indigenous peoples, for whom Russian is not a native language.

\section{References}

Bakieva, D.A. (2019). Kontseptsiia otkrytogo obrazovaniia: vzaimodeistvie sistemy i muzeiia [Concepts of open education: interaction of the system and the musem]. In Mezhdunarodnyi issledovatel'skii zhurnal [International Research Journal], 12-2 (90), 83-86.

Eremin, A.V., Orlova, O.N. (2020). Distantsionnoe obrazovanie kak odna iz form realizatsii kontseptsii otkrytogo obrazovaniia $\mathrm{v}$ mirovom masshtabe [Distance education as a form of implementing the concepts of open education at the world scale]. In Pozharnaia i teknosfernaia bezopasnost': problemy i puti sovershenstvovaniia [Fire and technological safety: problems and ways of improvement], 1 (5), 254-256.

Efimov, V.S. (2015). Stanovlenie otkrytogo obrazovaniia: smysl i zadachi (ontologicheckie zametki) [Formation of open education: meaning and goals (ontological notes). In VNEshkolnik, 1 (163), 20-23.

Ivanova, N.A. (2009). Tsentr otkrytogo obrazovaniia [Open Education Centre]. In Vysshee obrazovanie $v$ Rossii [Higher education in Russia], 12, 71-75.

Natsional'nyi proekt "Obrazovanie" ["Education" national project]. Available at: https://futurerussia. gov.ru/obrazovanie

OON lishit russkii iazyk statusa "mezhdunarodnogo iazyka [The UN will deprive the Russian language of the international language status]. In Russkii evrei [Russian Jewish]. Available at: http://rusjev. net/2015/07/22/oon-lishit-russkiy-yazyik-statusa-mezhdunarodnogo-yazyika/ accessed on 22.07.2015.

O russkom slove. Beseda s chlenom-correspondentom Rossiiskoi Akademii nauk Nikolaem Skatovym [About Russian word. Talking to a corresponding member of the Russian Academy of Sciences Nikolay Skatov] (2007). In Russkaia narodnaia liniia [Russian folk line]. Available at: https://ruskline.ru/analiti$\mathrm{ka} / 2007 / 06 / 08 / \mathrm{o}$ russkom slove

Parygina, T.S., Terov, A.A. (2016). Perspektivy distantsionnogo obucheniia v usloviiakh otkrytogo obrazovaniia [Prospect of distance learning under the conditions of open education]. In Ekonomika. Obrazovanie. Pravo [Economics. Education. Law]. Studies of the state and development of modern society. Collection of scientific works based on the materials of international scientific conference. 657-660.

Poláková, P., Klímová, B. (2019). Mobile Technology and Generation Z in the English Language Classroom. A Preliminary Study. Educ. Sci., 9, 203.

Stenogramma vstrechi V.V. Putina s deiateliami kul'tury v rezhime videokonferentsii ot 06 iiunia 2020 [Records of V.V. Putin's meeting with activists of culture by means of video conferencing on June $\left.6^{\text {th }}, 2020\right]$. Available at: http://kremlin.ru/events/president/news/63462

Stenogramma Zasedaniia Soveta po russkomu iazyku ot 05 noiabria $2019 \mathrm{~g}$. [Records of the meeting of the Russian Language Council on November 5 ${ }^{\text {th }}$ 2019]. Available at: http://kremlin.ru/events/president/ news/61986

Strategiia natsional'noi bezopasnosti Rossiiskoi Federatsii (utv. Ukazom Prezedenta RF ot 31 dekabria 2015 g. N 683 [Strategy of the national security of the Russian Federation (confirmed with the Decree of the President of the Russian Federation on December 31 ${ }^{\text {st }}$, 2105]. Sistema GARANT. Available at: http://base. garant.ru/71296054/\#ixzz6bVQovr3h

Tait, Alan (2008). What are open universities for? In Open Learning: The Journal of Open, Distance and e-Learning, 23:2, 85-93, DOI: 10.1080/02680510802051871

Yaskevich, M.I. (2019). Massovye otkrytye onlain-kursy kak glavnaia tendentsiia razvitiia obrazovaniia [Mass open online courses as the main trend in education development]. In Kul'turnoe nasledie Rossii [Russian cultural heritage], 2, 79-84. Available at: https://cyberleninka.ru/article/n/massovye-otkrytye-onlai-n-kursy-kak-glavnaya-tendentsiya-razvitiya-obrazovaniya (accessed on 16.12.2020). 


\title{
Центр открытого образования
}

на русском языке «Сибирь.ру»:

концептуальные основания

и приоритетные направления работы

\author{
Г.А. Копнина, И.В. Евсеева, \\ Е.В. Еремина, Т.К. Веренич, И.В. Башкова \\ Сибирский федеральный университет \\ Российская Федераиия, Красноярск
}

\begin{abstract}
Аннотация. В публикации обоснована актуальность создания Центра открытого образования в Институте филологии и языковой коммуникации Сибирского федерального университета; обращено внимание на то, что открытые в высших учебных заведениях центры подобного типа существенно различаются структурой и целью, что связано с разным пониманием «открытости» образования; изложена концепция и перечислены основные направления деятельности Центра открытого образования на русском языке «Сибирь.ру», созданного в СФУ при поддержке Министерства просвещения РФ (субсидии на реализацию мероприятий, направленных на полноценное функционирование и развитие русского языка); названы проведенные в рамках открытия этого Центра в октябре - ноябре 2020 г. дистанционные курсы и просветительные онлайн-мероприятия, в которых приняли участие слушатели из более чем семидесяти стран.
\end{abstract}

Ключевые слова: открытое образование, центр открытого образования, русский язык, русская культура.

Исследование выполнено при поддержке Министерства просвещения РФ (субсидии на реализацию мероприятий, направленных на полноценное функционирование и развитие русского языка, ведомственной целевой программы «Научнометодическое, методическое и кадровое обеспечение обучения русскому языку и языкам народов Российской Федерации» подпрограммы «Совершенствование управление системой образования» государственной программы РФ «Развитие образования»).

Научная специальность: 10.00 .00 - филологические науки. 